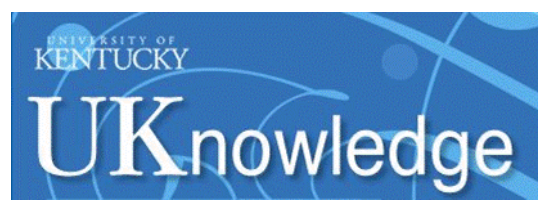

University of Kentucky

UKnowledge

$11-1978$

\title{
Reclaiming Coal Surface Mines in Central Appalachia: A Case Study of the Benefits and Costs
}

\author{
Richard C. Ausness \\ University of Kentucky College of Law, rausness@uky.edu \\ Alan Randall \\ Oren Grunewald \\ Sue Johnson \\ Angelos Pagoulatos
}

Follow this and additional works at: https://uknowledge.uky.edu/law_facpub

Part of the Energy and Utilities Law Commons, Environmental Law Commons, and the Natural Resources Law Commons

Right click to open a feedback form in a new tab to let us know how this document benefits you.

\section{Repository Citation}

Ausness, Richard C.; Randall, Alan; Grunewald, Oren; Johnson, Sue; and Pagoulatos, Angelos, "Reclaiming Coal Surface Mines in Central Appalachia: A Case Study of the Benefits and Costs" (1978). Law Faculty Scholarly Articles. 537.

https://uknowledge.uky.edu/law_facpub/537

This Article is brought to you for free and open access by the Law Faculty Publications at UKnowledge. It has been accepted for inclusion in Law Faculty Scholarly Articles by an authorized administrator of UKnowledge. For more information, please contact UKnowledge@lsv.uky.edu. 


\section{Reclaiming Coal Surface Mines in Central Appalachia: A Case Study of the Benefits and Costs}

\section{Notes/Citation Information}

Alan Randall, Oren Grunewald, Sue Johnson, Richard Ausness \& Angelos Pagoulatos, Reclaiming Coal Surface Mines in Central Appalachia: A Case Study of the Benefits and Costs, 54 Land Economics 472 (1978). 


\section{Reclaiming Coal Surface Mines in Central Appalachia: A Case Study of the Benefits and Costs}

\section{Alan Randall, Orlen Grunewald, Sue Johnson, Richard Ausness and Angelos Pagoulatos}

Regulatory alternatives for the surface mining industry have come under intense public and political scrutiny in recent years. While the political concerns may have peaked with the passage of the federal Surface Mining Control and Reclamation Act of 1977, there remains (as of this writing) the intense lobbying, debate and, one might expect, litigation over the regulations which will be adopted to implement the Act.

As a result of a rather small volume of high quality economic analysis in the last few years, there now exists a literature on the economic impacts of various regulatory alternatives for the reclamation of coal surface mines. In broad summary, recent studies have found that the impacts of federal surface mine reclamation regulations $^{1}$ will be noticeable, but perhaps not as substantial as some had expected. Nationwide, coal production from surface mines would be reduced by about five percent, with a similar increase in underground coal production [Schlottmann and Spore 1976; ICF, Inc. 1977]. In Appalachia, the effects, both reducing surface mine output and increasing underground production, would be a little more pronounced [Schlottmann and Spore; ICF, Inc.]. Nevertheless, the total decrease in Appalachian coal output and employment in coal mining was pro- jected to be quite small, i.e., on the order of two percent [Lin, Spore and Nephew 1976]. These findings suggest that federal reclamation legislation, depending on the regulations eventually adopted for its implementation, is unlikely to be a major disruptive influence in the coal industry, or a substantial impediment to the long-run national goal of increased utilization of coal.

None of the above-mentioned studies,

\footnotetext{
Randall, Grunewald and Pagoulatos are with the Department of Agricultural Economics, Johnson is with the Center for Developmental Change, and Ausness is with the School of Law, all at the University of Kentucky, Lexington. The authors are grateful to Donald Batch, Webb Smathers and John Stoll for important contributions to key elements of this research. The suggestions of two reviewers prompted significant improvements in this article.

This paper (78-1-7) is published with the approval of the director of the Kentucky Agricultural Experiment Station. The research upon which it is based was funded in large part by the U.S. Environmental Protection Agency, under contract number 68-01-3586. Opinions expressed herein do not necessarily represent those of the sponsoring agency.

1 The studies cited and the study reported in this article were completed before the Act emerged from House-Senate Conference in final form. Regulations for implementation of the Act are yet to be adopted. Accordingly, none of these studies analyze the forthcoming regulations in precise detail. Rather, they focus on the broad outlines of federal surface mine regulation as visible in earlier drafts of the Act. Discussion and analysis of Kentucky state regulations, in this article, refers to the regulations current in 1976 .
} 
however, has addressed itself to the benefits which accrue from surface mine reclamation under current state regulations, or which could be expected to occur when federal legislation is implemented. Here, we report the results of a study which is addressed specifically to estimation of the benefits from surface mine reclamation in a case study region of central Appalachia. Our estimates of the benefits of reclamation can then be compared with reclamation costs, as estimated by the researchers cited above.

Our findings, in brief, are that, for our study region, the benefits of reclamation occurring under Kentucky regulations as of 1976 are unambiguously in excess of reclamation costs; the incremental benefits of reclamation under the federal bill as introduced in the 1977 Congress are positive, and, under certain assumptions, exceed the costs; and, even assuming the universal application of the best available reclamation technologies in the study region, surface mining for coal would generate some residual external costs.

\section{THE STUDY REGION}

The study area is the watershed of the North Fork of the Kentucky River, an area of about 1,600 square miles. The terrain is mountainous with narrow valleys, and is typical of the central and southern Appalachian coalfields. The area has experienced both deep and surface mining for coal, and surface mining has expanded in recent years. In 1974 , there were 157 active surface mines, which produced 11.2 million tons of coal [U.S. Bureau of Mines 1975]. Permits for surface mining of 21,500 acres were active as of March 31, 1976.

The regional population is in the neighborhood of 80,000 living in small cities, villages and the countryside. Hazard, the largest city, has a population of around 9,000. Coal mining is the major basic industry, far surpassing agriculture and forestry in the value of output.

The socioeconomic status of the population is typical of the central Appalachian coalfields. Incomes are lower, families are larger and the dependency ratio is greater than the national average. Outmigration of the economically self-sufficient segments of the population proceeded rapidly in the two decades following 1950. During the 1970s, however, the improved economic prospects in the coal industry, which coincided with a period of economic uncertainty in the national industrial sector, have led to increased regional employment and incomes and some return migration [Randall et al. 1978].

The surface mining industry in the region has major environmental impacts. Mining typically takes place on slopes in excess of $\mathbf{2 0}$ degrees, and often greater than 25 degrees. The contour mining method is commonly used, and state regulations (KRS Chapter 350), as revised in 1974 , permit forty percent of the overburden to be placed beyond the solid bench, that is, pushed down the outslope. While current regulations require that overburden be stabilized, the exposed seam and all acid-bearing and toxic materials be buried, the bench be revegetated, and run-off be collected in silt control structures, negative environmental impacts persist. Highwalls remain exposed, aesthetic impacts are significant, slides occur when spoil stabilization is inadequate, streams suffer siltation, and water quality is diminished by suspended sediment and polluted by various chemicals.

In recent years, a mining technique 
known as mountaintop removal, a remarkably appropriate descriptive term, has become popular in the region. This process leaves a plateau where there once was a sharply peaked mountain, and thus may encourage post-reclamation land uses of the type for which moderate to large contiguous areas of relatively flat land are preferred. However, while the environmental impacts of mountaintop removal differ in kind and degree from those of contour mining, mountaintop removal generates environmental impacts in most of the categories enumerated above.

\section{THE BENEFITS OF RECLAMATION: A CONCEPTUAL FRAMEWORK}

Surface mining is performed by the private sector, which bears the private costs of mining and is rewarded with income from the sale of coal. However, the environmental damage which occurs during and after surface mining is mostly in the nature of an external diseconomy. The industry visits external costs upon owners of land adjoining the mine site, residents of the mining region, downstream users of water impacted by mining, and nonregional residents who visit the region, may visit the region in the future or may simply suffer disutility from the knowledge that the regional environment is being damaged. As a result of surface mining, private and social costs (benefits) are unequal. Thus, economic inefficiency is endemic, in the absence of some collective action such as regulation or redefinition of property rights.

Surface mining affects resource quality, in particular the quality of land, water and biological resources. As a result of surface mining, the net benefits which may be derived from concurrent and subsequent uses of these resources may be increased or decreased. Assuming, realistically, that the absolute value of the decreases exceeds that of the increases, the economic costs of environmental damage due to surface mining are equal to the reduction in the net benefits generated from concurrent and subsequent uses of the impacted resources.

Symbolically, let $C\left(t_{o}\right)$ denote the present value in time $t_{o}$ of the sum of the net environmental costs accruing in each time period $t\left(t=t_{o}, t_{o}+1, \ldots, T\right)$ as a result of surface mining in the study region in time period $t_{o}$. Thus,

$C\left(t_{o}\right)=\sum_{t_{o}}^{T} P V\left[\sum_{1}^{J} \sum_{1}^{K} c(t)_{j k}\right]$

where $P V=$ present value, and $c(t)_{j k}=$ the net loss accruing in time $t$ of social benefits derived from resource using activity $k(k=1, \ldots, K)$ due to the change $j(j=1, \ldots, J)$ in resource quality which resulted from mining in time $t_{o}$.

Further,

$c(t)_{j k}=\int \frac{Q_{j}^{w}}{Q_{j}^{o}} \pi_{k}^{\prime} d Q_{j}$

where $Q_{j}^{o}, \ldots, Q_{j}^{w}=$ a continuum of quality levels of the resource $j$ from the nomining situation, $Q_{j}^{o}$, to the level with mining, $Q_{j}^{w}$, and $\pi_{k}=$ the net social benefits of resource using activity $k$, and $\pi_{k}^{\prime}$ is thus the marginal change in $\pi_{k}$ as a result of a change in $Q_{j}$.

The resource quality changes occurring as a result of mining are hypothesized to affect the net benefits of resource using activity $k$ both directly and indirectly, that is, having a direct effect through their influence on the quantity and quality (and hence value) of outputs being produced and an indirect effect through their influence on the quantities (and hence costs) of inputs needed to 
produce each unit of output. These various effects may, as the case may be, take positive, negative or zero values.

Together, equations [1] and [2] are used as the conceptual framework for estimating the economic costs of environmental damage from surface mining. Resource quality changes are identified and quantified. Then, the changes in the net benefits of each resource-using activity, resulting from resource quality changes, are identified, estimated, reduced to present value and summed.

Given that precautions and treatments to reduce off-site damage during and after mining and to reclaim mined land cause a reduction in the economic costs of surface mining damage, ${ }^{2}$ reclamation benefits are defined as the resulting decrement in external costs, that is, the increment in net social benefits, of surface mining.

\section{THE BENEFITS OF RECLAMATION: EMPIRICAL ESTIMATES}

In order to develop empirical estimates of the benefits of reclamation under Kentucky regulations and proposed federal regulations, we proceed as follows. First, the present value of the net economic costs of environmental damage from surface mining in the study region in 1976 is estimated. These costs are residual environmental costs after all benefits from Kentucky state regulations, as of 1976, have been obtained. Second, the economic costs of damage which would have occurred had surface mining been unregulated in 1976 are estimated. The difference between these two estimates is the economic value of the environmental benefits from existing Kentucky regulations. Third, the economic costs of damage which would occur under pro- posed federal regulations are estimated. The difference between the first and third amounts is the economic value of the incremental environmental benefits which would be obtained as a result of federal regulations, given the prior existence of state regulations.

\section{Difficulties in Empirical Estimation of Reclamation Benefits}

In order to accurately estimate the economic value of the environmental benerits from surface mine reclamation, a quite massive array of information is necessary. The required information includes both economic information, to estimate prices of goods which are exchanged in reasonably competitive markets and values of goods and amenities which are not, and information from the natural sciences, to determine the technical relationships between mining and resource quality and between resource quality, production of goods and amenities, and input requirements in these production processes. In this study, no categories of benefits are omitted on account of the lack of economic value data. On the other hand, there are a few categories of benefits which are omitted for lack of technical productivity estimates (e.g., in-region recreation benefits). In each category, estimation methods are explained, major data sources are identified and, where appropriate, reference is made to Randall et al. [1978] in which additional detail is provided.

Before one sets out to examine our estimates of the benefits of reclamation in the study region, it is instructive to

\footnotetext{
2 The somewhat separate processes of reducing off-site damage during and after mining and reclaiming mined land will be considered together and, rather loosely, called "reclamation" in this article.
} 
briefly review the estimates presented by Howard [1971], who has provided the only previously published estimates of reclamation benefits in eastern Kentucky. Howard estimated the benefits from reclamation occurring from 1962 to 1967 , thus covering reclamation occurring under Kentucky regulations no more recent than the 1966 revisions. His external costs categories and the methods used to estimate external costs in the absence of reclamation are as follows: (1) Economic costs of water pollution due to acid runoff are derived from a 1964 report (which is actually an update of a 1940 survey) of the U.S. Public Health Service for the Appalachian region. It must be noted that acid run-off is a much less serious problem in eastern Kentucky than it is in northern Appalachia; the main water quality problems arising from surface mining in eastern Kentucky are sediment and hardness. (2) Costs arising from siltation and deposition of sediment are derived by estimating the costs of dredging affected streams and impoundments, which is, frankly, of limited technical feasibility and would result in environmental costs of its own. (3) Following a discussion which suggests that aesthetic damages to land are on the one hand non-trivial but, on the other, of "relatively low value" [p. 87], such damages are arbitrarily valued at $\$ 1.00$ per acre. (4) Losses incurred by owners of surface rights to land (in a region where mineral rights are commonly severed from and dominant to surface rights) are estimated arbitrarily at $\$ 1,000$ per incident, and the number of incidents is "indicated" [p. 91] by Kentucky Reclamation Division personnel. (5) Losses incurred by off-site land owners, as a result of landslides exacerbated by improper deposition of overburden, were estimated arbitrarily at $\$ 50$ per incident, and the number of incidents was reported by Reclamation Division personnel. (6) Costs were reduced to present value by discounting at 12 percent per annum, which is assumed to be the pre-tax return on investment expected by mine operators, rather than an estimate of the social discount rate.

While we are very much aware of the empirical difficulties faced by Howard in this 1971 study, we suggest that the estimation procedures reported below represent, in each case, substantial advances on those used by Howard.

External Environmental Costs of Surface Mining in the Study Region under Existing Kentucky Regulations, 1976

In this study, five broad categories of environmental damage were identified: (1) water pollution, as it affects domestic, commercial and industrial users of water; (2) degradation of life-support systems for fish, wildlife and recreation resources; (3) increased frequency and intensity of flooding; (4) damage to land, structures, and buildings; and (5) aesthetic damages. These categories of damage were carefully defined so as to be mutually exclusive and thus additive for the purpose of estimating total costs of damage.

In terms of our conceptual framework, the five damage categories may be described as follows: (1) is a case where the surface-mining-induced resource quality change necessitates additional inputs (water treatments) in order to produce a given quantity of output (water of acceptable quality for domestic, commercial and industrial use); (2) is a case where impaired resource quality directly affects the production of fish, wildlife and recreation resources, which contribute to human satisfactions; (3) is 
a case where impaired resource quality increases the frequency and intensity with which water in streams (a) becomes an intermediate discommodity, reducing the output of industrial processes, and (b) directly reduces human satisfactions; (4) is similar to (3), but addresses changes in the quality of the land resource, and (5) is a case where the quality of the land, water and biological resources is impaired, directly reducing human satisfactions.

To the extent feasible, these categories of damage were quantified in physical terms and their economic costs in each time period (i.e., year) subsequent to initial disturbance of land for mining were estimated. The present value of environmental costs in each time period was determined, in 1976 dollars, by discounting at 6 percent per annum (which we take to be a reasonable estimate of the social discount rate given that future costs are expressed in constant valued dollars) for 50 years or until technical information indicates that damage flows cease, whichever period is shorter. Cost streams were summed over time, to determine the present value of damage at the time of mining.

Immediately below, we present estimates of the annual costs of environmental damage occurring in the study region in 1976, as a result of surface mining for coal.

1. Water Treatment Costs. Monitoring data were obtained on 8 dates in 1974-75 at 38 locations within the Quicksand Creek watershed, a relatively large subwatershed of the study region, under the sponsorship of the Appalachian Regional Commission [1975]. The 18 water quality parameters monitored included sediment, $\mathrm{pH}$, conductivity, alkalinity, hardness, sulfates, chlorides, $\mathrm{K}, \mathrm{Na}, \mathrm{Mg}, \mathrm{Ca}$, $\mathrm{Al}, \mathrm{Sr}, \mathrm{Mn}, \mathrm{Fe}, \mathrm{Zn}, \mathrm{Cd}$, and $\mathrm{Pb}$. The above cited study did not include any sophisticated statistical analyses to identify the quantitative effects of surface mining on water quality parameters.

Pooling this time-series and cross sectional data, we estimated 18 water quality equations, each of the general form

$$
\begin{gathered}
Y_{t, i, j}=f\left[Y U_{t, i, j},\left(Y U_{t, i, j}\right)^{2}, M I N E_{i}, S L P E_{i},\right. \\
\left.D I S T_{i}, D_{2}, D_{3}, D_{4}, D_{5}, D_{6}, D_{7}, D_{8}\right]
\end{gathered}
$$

where

$t$
$i$
$j$
$Y$

$=$ date of monitoring;

$=$ location of monitoring site;

$=$ water quality parameter;

$=$ the dependent variable; thus $Y_{t, i, j}$ is the estimate of a given water quality parameter at a given monitoring site on a given day;

$Y U=$ concentration of the dependent variable at the monitoring point immediately upstream;

$M I N E=$ the surface mining activity in the immediate catchment of the monitoring site, measured as the proportion of the surface which is in a disturbed state;

SLPE = the slope of the mine site;

$D I S T=$ the distance of the stream from the location where surface mining is taking place;

$D_{d} \quad=$ dummy variable $(d=2, \ldots$ . ,8) where $D_{d}=1$ if data collected on $d$ th monitoring date, $=0$ if not.

MINE, SLPE, and DIST were determined from land use and topographical maps provided in Appalachian Regional Commission [1975].

Our general model is consistent with the state-of-the-art understanding of the 
relationships between surface mining and water quality. Omitted variables are those for which there was no variation in the data set and those micro variables, such as mining and reclamation technique, which were uncontrollable given the macro nature of the data.

These 18 water quality equations were estimated simultaneously using the seemingly unrelated regression (SUR) technique. This technique was appropriate since the 18 dependent variables are not unrelated, and hence intercorrelation may exist among the estimated error vectors across equations. In such circumstances, the SUR method will result in smaller variances for estimated coefficients than will OLS procedures [Kmenta 1971].

The most significant variable in explaining water pollutant concentrations was consistently found to be surface mining activity in the immediate catchment above the monitoring site (Table 1 ). This variable was significant at the 0.05 level of confidence for 14 of the 18 water quality characteristics (i.e., all except $\mathrm{Cl}, \mathrm{Al}, \mathrm{Zn}$ and $\mathrm{Pb}$ ) and, for many of them, was significant at much more stringent levels of confidence. $S L P E$ and $D I S T$ were seldom significant, not (we believe) because such variables are unimportant, but because there was little variation in these variables in our data set. The dummy variables, $D_{d}$, were mostly insignificant as expected. The upstream concentration of each pollutant, $Y U_{t, i, j}$, contributed to increased concentrations downstream. Curvilinear downstream effects were found for some, but not all, pollutants.

In the study region and downstream, water treatment occasioned by pollution from surface mining is limited to alum and lime treatment for turbidity, ${ }^{3}$ which also results in removal of some metal ions from the water and may cause an increase in hardness [Smathers 1974]. Using our estimates of the increment in sediment load attributable to surface mining, a model developed by Smathers [1974] which relates the use of alum and lime to turbidity (which is related to sediment), and current costs of water treatment inputs, it was found that additional costs of water treatment in the study region and downstream, attributable to surface mining in the study region, were $\$ 125,000$ annually. ${ }^{4}$

This represents a lower bound on the costs of damage to domestic, commercial and industrial water users since it does not address the possibility that some residual damage or utility loss may occur if existing water treatment practices, as seems likely, fail to eliminate all adverse impacts of mining. For example, delivered water tends to have high levels of hardness, and discoloration and impaired taste are occasionally observed.

2. Fish, Wildlife and Recreational Losses. There are indications from the scientific literature reviewed by Batch [1977] and the results of the personal interview survey conducted during this study [Randall et al. 1978] that surface mining has been associated with declining opportunities for hunting and fishing in the study region. ${ }^{5}$ In addition, to the extent that surface mining in the study region diminishes water quality down-

\footnotetext{
${ }^{3}$ An extensive telephone survey of major waterusing industries found none which treat water beyond the treatments provided by water companies and municipal water systems.

4 Complete details of the relevant calculations are to be found in Randall et al. [1978].

5 In some other regions, it has been suggested that reclaimed surface mine sites may offer recreational opportunities which are superior to those offered by the unmined environment. To our knowledge, such claims have never been put forward seriously in our study region.
} 
stream, losses in the value of waterbased recreation activities will be incurred downstream from the study region.

It was possible to quantify only a subset of the total fish, wildlife and recreational losses. Due to the highly unsatisfactory recreational data base for the study region, in-region hunting and recreational losses remain unquantified, while in-region fishing losses are quantified only to the extent of estimating fish replacement costs.

In a series of experiments involving fish counts in streams in the study region prior to and after surface mining, Batch [1977] determined the fish losses which are attributable to mining. He then calculated fish replacement costs (i.e., costs of purchasing fish and restocking streams with them). Assuming that it would be unwise to attempt restocking sooner than five years after initial disturbance of the headwaters for mining, the annual costs of fish replacement were calculated, from Batch's data, to be $\$ 65,300$ [Randall et al. 1978].

Recreational losses due to degradation of water quality downstream in the main Kentucky River were estimated by, first, determining the reduction in recreational use which can be attributed to water quality impairment and, then, estimating the value of the recreation lost. Expected recreational use of the main Kentucky River was calculated by applying relevant local data (which included market area demographic data, and an inventory of alternative recreation sites in the market area) to a recreation demand model adapted from Appalachian Regional Commission [1969]. Expected use was then compared with the actual use, as recorded by the U.S. Army Corps of Engineers. ${ }^{6}$ Actual use was substantially less than expected use. However, all of the shortfall in recreational use cannot be attributed to turbidity of the river caused by mining in the North Fork. Making the most reasonable estimate following discussions with lock managers, we attributed one half of the estimated shortfall in recreational use to turbidity which makes the river less attractive than many reservoirs in its market area. The other half of the shortfall was attributed to the rather limited access which is available on some of the stream segments (access to other stream segments is excellent). Then, using stream flow data and our water quality equations, the proportion of the total sediment load in the main Kentucky River which could be attributed to mining in the North Fork was estimated. This enabled calculation of the number of recreation days lost on the main Kentucky River due to water quality impairment attributable to surface mining in the North Fork. Valuing these lost swimming, fishing and boating days at the mid-range of the current Water Resources Council user day values, the annual downstream recreational losses due to surface mining in the North Fork were estimated at $\$ 211,500$.

Thus, total quantified fish, wildlife and recreational losses were about $\$ 277,000$ annually. These estimates, in so far as they go, seem to be quite good "ballpark" estimates. However, they represent an underestimate of total fish, wildlife and recreational losses since the following categories of loss remain unquantified: in-region hunting and recreational losses, in-region fishing losses in excess of fish replacement costs, and losses suffered by the small commercial

\footnotetext{
6 The main Kentucky River, from the confluence of the North and South Forks to the confluence of the Kentucky and Ohio Rivers, is divided by 14 locks into 15 stream segments. The Corps, which manages the river and operates the locks, records all actual recreational use on all stream segments.
} 


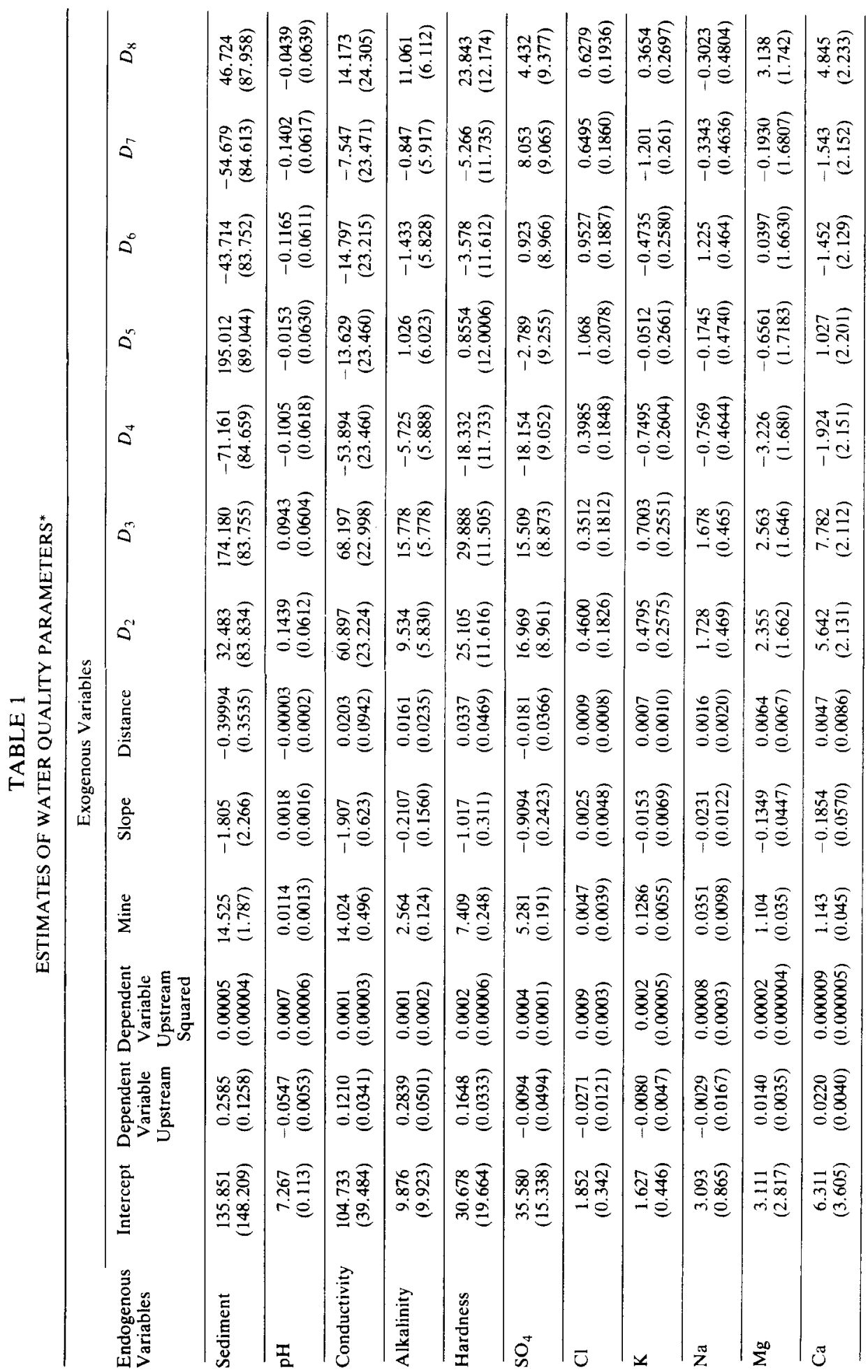




\begin{tabular}{|c|c|c|c|c|c|c|}
\hline $\begin{array}{l}\infty \widehat{\hat{n}} \\
\infty \\
\infty \\
1 \\
1\end{array}$ & 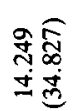 & 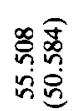 & 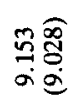 & 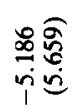 & 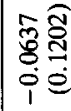 & 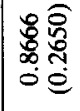 \\
\hline $\begin{array}{l}\hat{n} \\
\hat{n} \\
0 \\
0 \\
0\end{array}$ & 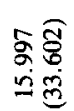 & 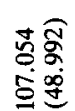 & 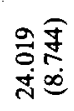 & 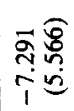 & 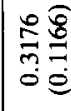 & 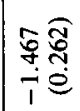 \\
\hline 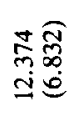 & 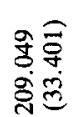 & 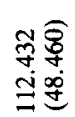 & 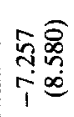 & 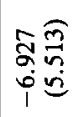 & 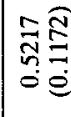 & 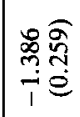 \\
\hline 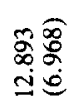 & 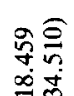 & 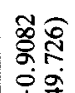 & 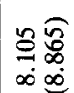 & $\begin{array}{l}\text { no } \\
\infty \\
\infty \\
i \\
i\end{array}$ & 赵司 & 高客 \\
\hline & $\underset{\sim}{\infty}$ & 19 & & 70 & & \\
\hline 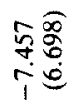 & 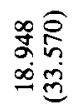 & 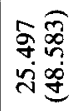 & 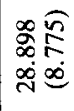 & 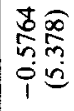 & 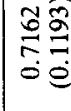 & 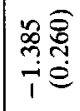 \\
\hline 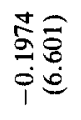 & $\begin{array}{l}\infty \widehat{\infty} \\
\infty 心 \\
\infty \\
\infty \\
\infty \\
\infty \\
\infty\end{array}$ & 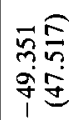 & 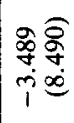 & 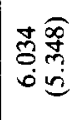 & 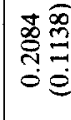 & 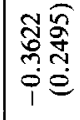 \\
\hline 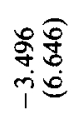 & 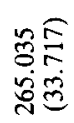 & 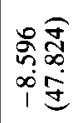 & 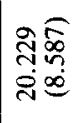 & 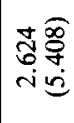 & 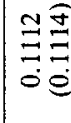 & 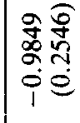 \\
\hline 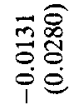 & 象高 & 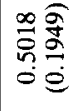 & 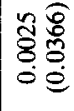 & 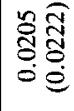 & 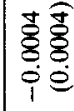 & 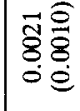 \\
\hline $\begin{array}{l}\frac{0}{0} \\
\frac{8}{0} \\
0\end{array}$ & 㞭各 & 总 & 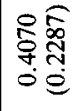 & 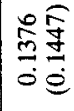 & 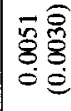 & 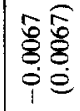 \\
\hline 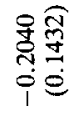 & 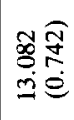 & 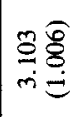 & 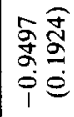 & 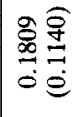 & 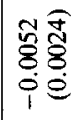 & 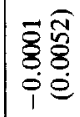 \\
\hline 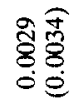 & 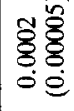 & 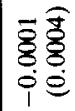 & 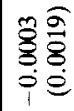 & 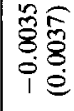 & $\mid \begin{array}{ll}n & 0 \\
0 & 0 \\
0 & 0 \\
1 & 0\end{array}$ & 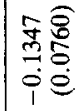 \\
\hline 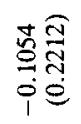 & 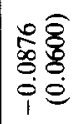 & 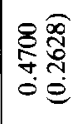 & $\frac{\infty}{2} \frac{a}{0}$ & 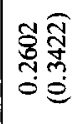 & $\begin{array}{l}\text { च̃ } \\
\stackrel{0}{0} \\
0 \\
0\end{array}$ & 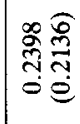 \\
\hline लि & 范尔 & 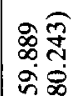 & 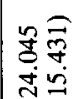 & 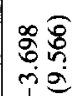 & 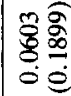 & 卷尊 \\
\hline$z$ & is & $\mid \Sigma$ & 证 & กี & 18 & 10 \\
\hline
\end{tabular}

fishing industry in the lower North Fork and the main Kentucky River. The secondary data on the commercial fishery was inadequate to permit even a "ballpark" estimate of the losses in potential productivity that it may be suffering.

3. Flooding. Surface mining disturbs the land surface and increases run-off from sudden storms. In addition, it increases soil erosion which results in siltation of streams and reduces the capacity of streams to carry run-off water. Together, these two effects of surface mining increase the intensity and frequency of floods in the study region which, due to its topography, would be flood prone even in the absence of surface mining.

Curtis [1972], using data obtained from experimental sites in the study region, has estimated the relationship between surface mining activity and peak stream flows. Flood peaks increased by 73.3 percent after surface mining had disturbed about thirty percent of a small, carefully monitored, watershed. Given that approximately 1.5 percent of the surface of the study region is currently in a disturbed state due to surface mining, and assuming a linear relationship between marginal changes in flood peak and marginal changes in flood damages, ${ }^{7}$ it is estimated that 3.7 percent of the average annual value of flood damages in the study region can be attributed to surface mining. Downstream flood damages attributable to surface mining in the study region are trivial, since the main Kentucky River is well controlled and suffers fairly small flood damages, only a very small percentage of which could be blamed on mining in the North Fork.

\footnotetext{
7 Note that the actual relationship is unknown, but is most likely increasing. Thus, this assumption tends to result in underestimation of flood damages due to mining.
} 
The U.S. Army Corps of Engineers completed an analysis of flood damages in the study region in 1962 . We updated their estimates to 1976 economic conditions, and calculated the annual flood damages due to surface mining in our study region at $\$ 269,000$ (see Randall et al. [1978] for details of the calculation procedures). This is a reasonable "ballpark" estimate, perhaps a little on the conservative side, for reasons suggested in note 7 , and for the additional reason that the Corps data were confined to the value of property losses, etc., and did not include any direct measures of human disutility from flooding.

4. Damage to Land and Buildings. Surface mining causes on-site and offsite damage to land and buildings, as a result of land disturbance and the improper deposition and incomplete stabilization of spoil. In the absence of proper practices, landslides may destroy buildings and damage land off the mining site.

A personal interview survey of 220 randomly selected households, a one percent sample of the households in the study region, collected (among other things) data on the value of off-site damages to land and structures owned by respondents. The data obtained in this survey were aggregated across all regional households to estimate total regional off-site damages to land and structures. This estimate is accurate, within statistically estimable bounds, except to the extent that self-reporting of information by damaged parties may lead to bias.

The on-site losses in agricultural or forest productivity of mined land during mining are very small (since agricultural and forest productivity of land overlying coal reserves in the study region is typically low) and are more or less included in the private costs of mining since the mine operator customarily pays the surface right holder a small "access fee" per acre disturbed.

For the private purposes which are advanced by land ownership, properly reclaimed land is valued in the market more highly than unmined land, which in turn is valued more highly than mined but unreclaimed land. Reclaimed land is usually a plateau (following mountaintop removal) or a flat bench (following contour mining), while unmined land is mostly steep hillsides carrying a cover of scrub timber. The market values of unmined land, mined but unreclaimed land, contour mined and reclaimed land, and mountaintop removal mined and reclaimed land were determined through a telephone survey of regional realtors. The present value of the increment in the market value of mined and reclaimed land in the study region was calculated, and treated as an on-site benefit (a negative cost) of surface mining under existing Kentucky regulations.

The net value of damage to land and buildings due to surface mining in the study region was calculated, by subtracting the increase in value of reclaimed mine sites from the value of damage to land and buildings, to be $\$ 1,837,000$ annually.

5. Aesthetic Damages. Surface mining causes aesthetic damages to the landscape and to water. In the study region, aesthetic damage to water is mostly confined to increased siltation of stream beds (and the few small lakes in the study region) and increased sediment loads which make the water muddy. Discoloration of water due to acid mine drainage occurs at only a few locations in the study area. Aesthetic damage, assuming reclamation in compliance with Kentucky regulations, to the landscape occurs in the form of the drastic landscape modifica- 
tion resulting from mountaintop removal, and the exposed highwalls, flat benches and moderately sloped spoil deposits resulting from contour mining. In the absence of reclamation, aesthetic damage to the landscape is much more extreme.

The value of aesthetic damages was measured using a somewhat more sophisticated version of the iterative bidding technique first applied to valuation of aesthetic environmental improvements by Randall et al. [1974] . ${ }^{8}$ Bradford [1970] bid curves for reduction of aesthetic damage from surface mining were fitted, using three different vehicles for (hypothetical) collection of bids: an increase in the price of coal, an increase in the price of electricity generated from coal mined in the study region and a payment to a regional environmental improvement fund. The basic equation for the individual Bradford bid curves, which are indifference curves expressed in commodity/discommodity space (i.e., losses in budget versus increases in aesthetic amenities) and thus pass through the origin at the individual's initial state, was:

$$
\begin{aligned}
U\left(E^{\circ}, m^{\circ}\right) & =U\left[E^{\prime}, m^{\circ}+\left(p_{c}^{\circ} q_{c}^{\circ}-p_{c}^{\circ} q_{c}^{\prime}\right)\right] \\
& =U\left[E^{\prime}, m^{\circ}+\left(p_{e}^{\circ} q_{e}^{\circ}-p_{e}^{\prime} q_{e}^{\prime}\right)\right] \\
& =U\left(E^{\prime}, m^{\circ}+C\right)
\end{aligned}
$$

where $E=$ the level of aesthetic environmental quality; $m^{\circ}=$ the individual's initial level of money income; $p_{c}$ and $q_{c}=$ the price and quantity of coal consumed (directly and indirectly); $p_{e}$ and $q_{e}=$ the price and quantity of electricity consumed; $C=$ the money value of compensation received, and the superscripts, ${ }^{\circ}$ and ' , refer to the initial and final values, respectively.

Allowing $E^{\circ}$ to refer to the mined but unreclaimed aesthetic environment and
$E^{\prime}$ to represent an environment mined and reclaimed, $C,\left(p_{c}^{\circ} q_{c}^{\circ}-p_{c}^{\prime} q_{c}^{\prime}\right)$ and $\left(p_{e}^{\circ} q_{e}^{\circ}-p_{e}^{\prime} q_{e}^{\prime}\right)$ must be equal to one another, and all must be less than zero. That is, each represents a negative compensation, i.e., a positive willingness to pay (WTP) for improved aesthetic environmental quality. Taking $E^{\circ}$ as the initial level of environmental quality, and observing that the data collection instrument confronted respondents with specified levels of aesthetic environmental quality (from which they could not adjust), the individual WTP data collected may be identified as estimates of the Hicksian compensating surplus value of aesthetic environmental improvements. As such, these estimates are conservative estimates of value. ${ }^{9}$

Four environments-(A) mined but not reclaimed, (B) partial reclamation, (C) state-of-the-art reclamation, and (D) never mined (representing "perfect" restoration of the landscape)-were presented in the form of photograph sets to 220 randomly selected respondents representing a one percent sample of households in the study region. In addition to valuing each environment by iterative bidding, each respondent ranked the four environments on a non-monetary preference scale. The results using all four test items were remarkably consistent. Statistical testing resulted in rejection of hypotheses that the iterative bidding results were influenced by the bidding vehicle or by the starting bid posited to respondents.

Results obtained by iterative bidding

\footnotetext{
8 The Randall et al. [1974] results were replicated in a later study by Brookshire et al. [1976].

9 The WTP measure of value generates, for normal goods, a smaller absolute value than the willingness to accept compensation (WTA) measure [Willig 1976, and Randall and Stoll 1978].
} 
were aggregated over the study region to determine regional willingness to pay (RWP) for aesthetic environmental improvements. The value of aesthetic environmental damage occurring under existing Kentucky regulations amounted to $\$ 1.048$ million (RWP) annually. An alternative aggregation method could be applied not only to coal consumed (directly and indirectly) by regional residents, but also to all people who use products made using coal produced in the region. Using this second aggregation procedure, the total consumer payment (TCP) estimate of the value of aesthetic environmental damage amounted to $\$ 56.487$ million annually. Clearly, as the disparity between RWP and TCP suggests, the study region suffers the environmental impacts of mining coal which is used in the production of goods consumed mostly in other places.

Some discussion of these two estimates of the value of aesthetic damages from surface mining seems necessary. RWP is strictly an underestimate (or a lowerthan-lower-bound estimate), since it excludes any negative value which visitors to the region may place on environmental damage and any option and existence values which those who do not currently use the study region environment may place on its quality. In addition, RWP is strictly limited by the budget constraints of regional residents, and thus is consistent with the ethical position sometimes called "victim pays", that they alone should bear the environmental costs which are ipso facto assumed to be limited to the amount they can afford to pay for relief. The ethical position underlying TCP is perhaps more appealing: all who use the products of the mining activity should contribute to the alleviation of its ill effects, and pay at the same rate as regional residents. On the other hand, we would expect that TCP overestimates the amount that consumers are truly willing to pay. Finally, it must be noted that RWP and TCP are not alternative estimates of the same quantity but, for the reasons discussed above, estimates of two fundamentally different quantities.

6. Total Costs of Environmental Damage Due to Surface Mining. The annual cost of damages in each of the above categories was summed to determine the total costs of environmental damages accruing in 1976 from surface mining in the study region in 1976 and all previous time periods (Table 2 ). Then, it was necessary to calculate the present value of the time stream of environmental damages resulting from the surface mining of one ton of coal, and one acre of land, at time $t_{o}$ under existing Kentucky regulations. To permit these calculations the following reasonable technical assumptions were made: flooding, water-based recreational and water treatment damages will be at their highest levels in years 1 through 3 following mining; and will be exhausted by year 5 ; damage to land and buildings will occur in years 1 and 2 , when substantial earthmoving is under way; the mined environment is in aesthetic state $A$ for three years after the initiation of mining, state $B$ for the next 5 years and state $C$ thereafter. ${ }^{10}$ Given these assumptions and data on the total areas of land mined and reclaimed in 1976 and each previous year, ${ }^{11}$ the

\footnotetext{
${ }^{10}$ Aethetic state D may be achieved, on contour mining sites only, after 23 years following the initiation of mining, and only under federal regulation which requires back-to-contour reclamation. Aesthetic states A through $D$ are defined in the section on "aesthetic damages."

11These data were obtained from surface mining permits issued in the study area, and Appalachian Regional Commission [1975].
} 
TABLE 2

TOTAL ANNUAL COSTS OF ENVIRONMENTAL DAMAGE FROM SURFACE MINING IN THE STUDY REGION (1976)

\begin{tabular}{lcc}
\hline Category of Costs & $\begin{array}{c}\text { TCP } \\
\text { (\$ millions) }\end{array}$ & $\begin{array}{c}\text { RWP } \\
\text { \$illions) }\end{array}$ \\
\hline Water Treatment & 0.125 & 0.125 \\
Fish, wildlife and & & \\
$\quad$ recreational & 0.277 & 0.277 \\
Flooding & 0.269 & 0.269 \\
Land and buildings & 1.837 & 1.837 \\
Aesthetic & 56.487 & 1.048 \\
$\quad$ TOTAL & 58.995 & 3.556 \\
\hline
\end{tabular}

present value, in 1976 dollars, of environmental costs of disturbing one acre of land was calculated. The environmental costs of mining one ton of coal were calculated by assuming that 2,000 tons of coal are obtained for each acre disturbed by mining. ${ }^{12}$

Under existing Kentucky regulations, as of 1976, the present value of the environmental costs of mining one ton of coal is estimated to be $\$ 9.10$ (TCP) or $\$ 0.40$ (RWP). The present value of the environmental costs of disturbing one acre of land for coal mining in the study region is estimated at $\$ 18,204$ (TCP) or $\$ 793$ (RWP).

\section{BENEFITS AND COSTS OF RECLAMATION UNDER EXISTING STATE REGULATIONS}

In order to estimate the benefits of reclamation, it is first necessary to estimate the value of environmental damage which would occur in the absence of any reclamation effort. This was done using the data generated in the course of estimating the value of damages under existing regulations, and a series of newly estimated technical parameters relating unregulated mining with resource quality changes. 13

It is estimated that under a no-reclamation regime, the present value of damage from disturbing an acre of land would be $\$ 40,788$ (TCP) or $\$ 3,833$ (RWP), and for mining a ton of coal would be $\$ 20.39$ (TCP) or $\$ 1.90$ (RWP). By subtraction, the benefits from reclamation under existing reclamation amount to $\$ 11.29$ (TCP) or $\$ 1.50$ (RWP) per ton of coal mined. The best available estimate of the cost of reclamation, in the study region, to meet existing regulations is about $\$ 0.81$ per ton of coal mined for operating costs and an additional $\$ 0.29$ (average cost per ton) for "front-end" costs which include capital and permitting costs. ${ }^{14}$ Thus, it is clear that the aggregate benefits from reclamation under existing Kentucky regulations exceed the private costs to the mining industry, regardless of whether benefits are estimated as TCP or RWP. These aggregate benefits and costs of reclamation may be interpreted as the incremental benefits and costs of introducing the Kentucky regulations into an unregulated legal environment for surface mining.

\footnotetext{
12 This estimate is within the range reported by Howard [1971], and is slightly higher than the estimate used by ICF, Inc. [1977]. Note that overestimation of the coal yields per acre disturbed would result in underestimation of environmental costs and reclamation benefits per ton.

13 The technical parameters of resource quality change under a no-reclamation regime and under federal regulation (see below) were established by the authors, on the basis of the existing technical literature and with the benefit of consultation with J. D. Brackenrich, P.E., mining and reclamation consultant.

14 Reclamation cost estimates are derived by adaptation of the estimates presented by ICF, Inc. [1977]. In particular, considerable use was made of Table 2-20 and Table 9, page E12, in ICF, Inc. [1977]. The estimates presented by ICF, Inc. make use of information in Nephew and Spore [1976] and U.S. EPA [1976].
} 


\section{BENEFITS AND COSTS OF RECLAMATION UNDER FEDERAL REGULATIONS}

Similarly, it was calculated that the benefits of incremental environmental improvements under federal surface mine reclamation regulation would be $\$ 3.62$ (TCP) or $\$ 0.19$ (RWP), while the incremental private costs of meeting such regulations would be about $\$ 1.72$. Thus, the aggregate incremental benefits (measured as TCP) from federal regulation, given the existing Kentucky regulations, exceed the private costs, while when measured as RWP, they do not. Our findings with respect to the benefits and costs of federal regulations are thus inconclusive.

At this point it is appropriate to remind the reader that the RWP estimate of the total benefits of reclamation is a clear underestimate, since it includes a lower-than-lower-bound estimate of aesthetic damages and a clear underestimate of damages to fish, wildlife and recreation related activities. In addition, any omissions in the estimation of damages due to flooding and increased water treatment costs are of the kind which would lead to underestimation. On the other hand, the TCP estimate of aesthetic benefits (the only benefit category in which the RWP and TCP estimates differ) is almost surely an overestimate of willingness to pay.

\section{RESIDUAL ENVIRONMENTAL DAMAGE}

There is evidence that the environmental costs of surface mining in the mountainous central Appalachian environment will always be positive. Given full compliance with federal regulations, we estimate that damages of $\$ 5.48$ (TCP) or $\$ 0.21$ (RWP) present value per ton of coal mined would remain. This damage would occur largely during and immediately following mining, since the most effective known practices cannot eliminate all on-site and off-site impacts of overburden removal and deposition. In addition, there is an establishment period following revegetation which may extend from several to more than twenty years, depending on the selection of herbaceous or tree species for revegetation. Finally, the results of iterative bidding and the non-monetary preference indicator made it very clear that regional residents perceive the fully reclaimed environment (unless, perhaps, back-tocontour reclamation is totally effective) as aesthetically inferior to the never mined environment. If it were technically feasible and required by enforceable regulations to eliminate all external costs except aesthetic damage during the period from the initiation of mining to the completion of "perfect" land restoration, unavoidable environmental costs of $\$ 5.38$ (TCP) and \$0.11 (RWP) per ton of coal mined would remain.

Sociological and attitudinal data were collected, along with environmental preference and iterative bidding data, during the personal interview survey. This survey reconfirmed the conventional wisdom that central Appalachian residents have a strong attachment to place and a love of the mountain environment. Sixty-four percent of respondents could trace their families' residence in the study region back 100 years or more. The following statements generated responses indicating a deep sense of the irreversibility of some surface mining impacts. "In the [study region], there are some places where the environment should never be 
disturbed" (90 percent agreement). "There is no need to preserve the beauty of the mountain environment for future generations" (85 percent disagreement). "Once surface mining has taken place, no matter how good are the efforts of reclamation, the land will never be exactly as it used to be" (73 percent agreement).

These attitudes and perceptions ought not be taken as evidence of massive local opposition to the surface mining industry. Twenty-seven percent of households had one or more members who worked (or had worked until retirement) in some aspect of the coal industry, while an additional 37 percent of respondents had one or more relatives (non-members of the household) with similar economic ties to the industry. Rather than massive opposition to the industry, our survey found a deep sense of helplessness among many residents, aue to their economic dependence on an industry of whose negative impacts they were deeply conscious.

\section{CONCLUSIONS}

This study has found that the social benefits from surface mine reclamation under existing Kentucky regulations unambiguously exceed the private costs. (Governmental costs of regulation have not been considered.) This finding may be contrasted with that of Howard [1971], who found that the benefits from the much less stringent 1966 regulations were exceeded by the costs of compliance. However, it must be pointed out that Howard used less defensible methods of determining the losses from water quality impairment, increased run-off, erosion, and sedimentation, and gave only per- functory consideration to slides, which he arbitrarily valued at $\$ 50$ per incident, and aesthetic damages, which he arbitrarily valued at $\$ 1.00$ per acre. Since the Kentucky regulations in effect in 1976 required a greater degree of effort in most aspects of reclamation (and no less effort in any aspect), compared with the 1966 regulations, one would expect that, if Howard used methods of the kind used in this study, he would have found the benefits of the 1966 regulations to be greater than the costs.

Utilizing the environmental damage estimates generated in this study for the "no reclamation," "reclamation to meet Kentucky standards," "reclamation to meet federal standards," and "reclamation to eliminate all but temporary aesthetic damages" cases, marginal benefits of reclamation were estimated and compared with marginal costs [Randall et al'. 1978, ps. 99-103]. I' was estimated that, if RWP is used as the measure of benefits, marginal benefits are equal to marginal costs at a level of reclamation effort about 30 percent greater than required under existing Kentucky regulations. If TCP is used, marginal benefits are equal to marginal costs at a level of effort just slightly greater than the federal legislation would require.

The above indications of the relationship between marginal costs and marginal benefits of reclamation must be interpreted with great care. Reclamation regulations are complex and typically address many concerns, including the following: permitting, bonding, deletion of areas from mining plans, surface devegetation, overburden removal and deposition, regrading, burying of toxic materials, run-off control, and revegetation. We have no evidence to indicate 
whether the Kentucky or the federal regulations represent an optimum mix of required practices, given the total costs they impose on coal operators. Similarly, we cannot be certain that there are no specific practices which are required by the Kentucky regulations at levels beyond the point where marginal benefits exceed marginal costs.

The incremental benefits of reclamation to satisfy the federal regulations which seem likely to be promulgated are always positive and exceed the incremental private costs under some assumptions (those used in deriving the TCP estimate) but not under others (those used in deriving the RWP estimate). It is clear that RWP underestimates the lower bound of the value of benefits from reclamation, but it is not known by how much the benefits are underestimated.

Regardless of the efforts made at reclamation, some residual costs of environmental damages (perhaps irreversible given current technology) from surface mining in the mountain environment remain and are perceptible to regional residents. This study suggests that, if an efficient level of reclamation could be precisely defined, the remaining environmental damage would be quite substantial. Such a finding would be totally consistent with economic theory, which suggests that the efficient degree of internalization of an external diseconomy will seldom eliminate all external costs. However, it is widely argued by environmental economists that the remaining external costs should not go unpriced. If the economic logic behind proposals for damage charges was applied to the surface mining situation, it would lead to proposals that surface miners reclaim the land to some efficient degree and pay charges equal to the social costs of remaining environmental damage.

\section{References}

Appalachian Regional Commission. 1969. Mine Drainage Pollution and Recreation in Appalachia (prepared by Robert R. Nathan and Associates, Inc.).

- 1975. Surface Mine Pollution Abatement and Land Use Impact Investigation, Report ARC-71-66-T2.

Batch, Donald. 1977. Impacts of Surface Mining on Fish and Wildlife. Department of Biological Sciences, Eastern Kentucky University, Richmond (mimeo).

Bradford, D. 1970. "Benefit/Cost Analysis and Demand Curves for Public Goods." Kyklos 23 (4): 775-91.

Brookshire, D.; Ives, B.; and Schulze, W. 1976. "The Valuation of Aesthetic Preferences." Journal of Environmental Economics and Management 3(Dec.): 325-46.

Curtis, W. R. 1972. "Strip-Mining Increases Flood Potential of Mountain Watersheds." Proceedings of National Symposium on Watersheds in Transition, American Water Resource Association and Colorado State University, Ft. Collins, Colorado, June 19-22.

Howard, H. A. 1971. "A Measurement of the External Diseconomies Associated with Bituminous Coal Surface Mining, Eastern Kentucky, 1962-1967." Natural Resources Journal 11 (Jan.): $76-101$.

ICF Incorporated. 1977. Energy and Economic Impacts of HR 13950 (Surface Mining Control and Reclamation Act of 1976). Washington, D.C.: Council on Environmental Quality and U.S. Environmental Protection Agency.

Kmenta, J. 1971. Elements of Econometrics. New York: MacMillan.

Lin, W. W.; Spore, R. L.; and Nephew, E. A. 1976. "Land Reclamation and Strip Mined Coal Production in Appalachia." Journal of Environmental Economics and Management 3 (Oct.): 236-52.

Randall, Alan; Ives, B.; and Eastman, C. 1974. "Bidding Games for Valuation of Aesthetic Environmental Improvements." Journal of Environmental Economics and Management 1 (Aug.): 132-49.

Randall, Alan; Grunewald, Orlen; Pagoulatos, Angelos; Ausness, Richard; and Johnson, Sue. 1978. Estimating Environmental Damages from the Surface Mining of Coal in Appalachia: $A$ Case Study. EPA-600/2-78-003, U.S. En- 
vironmental Protection Agency. Cincinnati (Jan.).

Randall, Alan, and Stoll, John. 1978. "Economic Surplus and Benefit/Cost Analysis" (manuscript).

Schlottmann, Alan, and Spore, Richard L. 1976 "Economic Impacts of Surface Mine Reclamation." Land Economics 52(Aug.): 265-77.

Smathers, Webb M., Jr. 1974. "The Economic Impact of Surface Mining on Water Quality." M.S. thesis, University of Kentucky, Lexington.

U.S. Army Corps of Engineers. 1962. Kentucky
Rivers and Tributaries. U.S. Army Engineer District, Louisville, Kentucky.

U.S. Bureau of Mines. 1975. Coal-Bituminous and Lignite in 1974. Mineral Industry Surveys, Washington, D.C.

U.S. Environmental Protection Agency. 1976. Development Document for Interim Final Effluent Limitation Guidelines and New Source Performance for the Coal Mining Point Source Category. Washington, D.C.

Wilig, R. D. 1976. "Consumer's Surplus Without Apology." American Economic Review 66 (Sept.): 587-97. 